\title{
Celebrity endorsement of political aspirants and its effects on college students in Lagos
}

Añulika Agina and Akpevwe Ekwevugbe

Pan-Atlantic University, Lagos

\begin{abstract}
This article examines two main research questions: what factors justify celebrity endorsement as an election campaign strategy given the increasing doubts associated with celebrity involvement in politics? Did celebrity endorsement of political aspirants influence young adults' voting behaviour during the 2015 elections in Lagos? Using mixed method approaches, and supported by source credibility and celebrity endorsement debates, a survey was conducted with a sample of 375 students of the Yaba College of Technology. Three semi-structured interviews with members of successful campaign teams were also conducted. Our findings revealed that campaign managers have huge confidence in the celebrity endorsement strategy for several reasons and would employ the approach in future. Further, the young people interrogated revealed that two-thirds of them are fans of Nollywood stars and music icons. But they were not influenced to vote on the basis of the celebrities' say-so. These findings are somewhat consistent with extant literature, but suggest the need for further studies regarding how celebrities translate fandom to votes.
\end{abstract}

Keywords: celebrity endorsement, celebrity, politics, voting behaviour, election campaigns, Nigeria

\section{Introduction}

Media celebrities are highly regarded in their societies; and this enables them function as effective promoters of persons, issues, products, and causes since they are perceived as believable, trustworthy, likeable and persuasive (Austin et al, 2008) agents. If a celebrity promotes a cause or a political candidate, then the media, the public and policy makers will take notice (Duncombe, 2007). Street (2002) states that social movements need to employ the use of celebrities to legitimize and promote their causes. Celebrities have been known to offer both their popularity and fame to social causes, brands or political and election campaigns. Once a cause can attract the attention of a celebrity, the celebrity could invite others through his or her own social network (Street, 2002). For instance, when celebrities mobilized efforts in campaigns like 'Rock the Vote', 'Vote or Die', 'Declare Yourself', it was observed by scholars that there is an inextricable link between politics and entertainment (Ridley, 2010; Brubaker, 2011). About 194 American celebrities including Oprah Winfrey, Will Smith, Tom Hanks, Jennifer Anniston, George Clooney, and Matt Damon supported the election of the first black US president, Barack Obama (Durante, 2012).

Political celebrity endorsement, by which is meant the practice of film and music stars publicly offering support to political aspirants during their election campaigns is on the rise. With the exponential growth of the entertainment industry particularly Nollywood and the 
music industries, celebrity culture has increased significantly in Nigeria. Originally confined to corporate brand endorsements, the practice has now been extended to endorsements of political aspirants. Recent studies (e.g. Tsika, 2015) in Nigerian celebrity culture tend to focus on the endorsement of products and services with little or no attention to political endorsements in the Nigerian space. Very little research has been conducted to determine the effects of celebrity endorsements of political candidates on voters (Garthwaite \& Moore, 2008). This is also true in the Nigerian context. The effectiveness of political celebrity endorsement in Nigeria is yet to be empirically examined. Therefore, the perceived effects of its continued use in elections remain largely anecdotal. Since endorsements of candidates by the local media, celebrities, or other political figures can have a direct or indirect effect on election outcomes as confirmed by Garthwaite and Moore (2008), it becomes necessary to conduct a study of this sort.

The purpose of this study is first, to determine the factors that justify the use of celebrities by political campaign managers and teams during the 2015 elections held in Nigeria; and second, to ascertain if and how indeed celebrity endorsement of political aspirants influence young adults' voting behaviour. By young adults, we mean college students aged between 18 and 25 years. This is because the eligible age for voting in Nigeria is 18 years; and people within that age bracket are avid followers of celebrities. In addition to that, Jackson and Darrow (2005) affirm that young people's adulation of celebrities makes them an attractive target for celebrity appeals. Further, young voters' attitudes and preferences regarding political candidates are often unstable (Burton \& Netemeyer, 1992), which easily makes them a campaign target. Celebrities can thus be described, not just as endorsers, but also as role models for fans (Brown, Basil \& Bocarnea, 2003) especially young adults. Add to that their celebrity role models as initiators or supporters of the campaign and persuasion is almost guaranteed. Although young adults show lower involvement and interest in politics and elections, Chou (2015) notes that appropriate communication through the right medium is likely to increase their engagement in the political process. These reasons validate the choice of the research subjects, and thus contribute to the discussion on if and how celebrities influence young adults' voting behaviour by their political endorsements.

Both quantitative and qualitative methods were employed in April 2016. Access to a large population of young adults from which a sample was drawn was obtained at the Yaba College of Technology in Lagos. Other higher education institutions from which samples could be drawn were on vacation at the time of this study, hence the focus on one such institution. To triangulate data sources, a simple random sampling technique was used to gather data from 375 students, three in-depth interviews were conducted with two campaign managers, Steve Ayorinde and Chude Jideonwo as well as with the only endorser, Uti Nwachukwu, accessible to us at the time. One of the limitations of this study is the fact of questioning respondents twelve months after the elections were conducted, which suggests that the interference of time and memory might hinder the provision of accurate details regarding voting behaviour. However, rigorous preparation of the research instrument, 
personally administering the questionnaire over two days and triangulation of data sources voters, campaign managers and celebrity endorser - mitigated the effects of this limitation.

We excluded celebrity-turned-politicians and crossover celebrity-politicians to focus on celebrities who use their fame to promote political aspirants and their causes. We also excluded several other campaign strategies such as the use of billboards, television and newspaper advertisements, thus adopting only the political celebrity endorsement strategy. Although fourteen political parties contested for the presidential election, this study restricted the political aspirants to the two dominant parties in the 2015 presidential election namely, the All Progressives Congress (APC) and the Peoples Democratic Party (PDP). The gubernatorial candidates were restricted to Lagos State, the second largest state by population size and the home of film and music celebrities in Nigeria. Lagos is the commercial nerve centre and media hub of Nigeria, with most, if not all, major media institutions located in the metropolitan city. In addition, the focus on celebrity endorsements of politicians and its effect on young adults' voting behaviour in the state that birthed the film and music industries of Nigeria makes the study location of Lagos an additional justification for conducting the study there.

\section{Celebrity endorsements and source credibility}

Traditionally, marketing campaigns used celebrities because the public views them as sources for lifestyle choices and cultural meanings (McCracken, 1989). This suggests that celebrities are largely emulated and their promotion of a cause would receive attention and influence opinions. Thus celebrity endorsement of politicians increases the exposure of the politicians to the public, and can also improve the involvement of voters in the election process. Advertisers use film, television, music or sports celebrities to promote their brands because consumers identify with success stories, and are led to thinking that the successes of the celebrities are transferred to the product or service advertised.

The focus of this paper is not the usual, more common celebrity endorsement of consumer brands or services used as persuasive marketing strategies. Rather, it is on the endorsements of political aspirants by celebrities, who people perceive as credible sources. Atkin and Block (1983) demonstrate that a source which is considered highly credible will most likely be more convincing than low credible sources. Source credibility and celebrity endorsement are related concepts which advance our understanding of persuasive communication. McCracken sees celebrity endorsement as 'any individual who enjoys public recognition and who uses this recognition on behalf of a consumer good by appearing with it in an advertisement' (1989, p.311). Such a definition is limiting as it ignores the growing political celebrity endorsements taking place around the globe. It also subtly initiates the debates around the validity of political celebrity endorsements. Whereas some authors (Jackson \& Darrow, 2005; Garthwaite \& Moore, 2008) postulate that celebrity involvement in promoting politicians' causes opens the doors to favourable election outcomes, others (Erdogan, 1999; West \& 
This is the version of the article accepted for publication in Journal of African Media Studies published by Intellect doi: 10.1386/jams.9.3.487 1

Accepted version downloaded from SOAS Research Online: http://eprints.soas.ac.uk/32045

Orman, 2002; Wood \& Herbst, 2007) express doubts as to whether film and music stars are sufficiently informed about political matters to influence voting behaviour.

Ohanian (1990) postulates that source credibility describes the positive attributes of the celebrity delivering the message, and the believability of that message. This point is extended by Ratneshwar and Chaiken (1991) who state that source credibility is the recipient's perception of the source's objectivity, expertise, and trustworthiness. Similarly, Belch and Belch (2001) affirm that the message from a credible source like a celebrity has the ability to influence beliefs, opinions, behavior and attitude through a process called internalization. This is based on the popular belief that the message from the source delivering it is accurate. Internalization happens when the influence of the source is accepted and manifested by the recipient in their attitude, personal attributes and value structures (Erdogan, 1999). Ohanian further states that the message will be more effective and the receiver would be more integrated, when the celebrity is perceived to be more trustworthy. The credibility feature often pertains to the celebrity's success in specific areas of performance known to the public, aided by the media coverage which such celebrities receive. This is supported by Ohanian, who notes that what really matters is the perceived audience opinion on the level of knowledge or expertise of the celebrity, a fact which campaign managers take to their advantage.

In the realm of political celebrity endorsement, Jackson and Darrow (2005) have established that candidates use celebrities to increase support from the audience, raise funds and mobilize voters. They also postulate that celebrities use their persuasive power to make unpopular candidates, causes, or ideas more attractive. They seem to suggest that the more accessible and familiar politics appears to be, owing to the celebrities involvement in it, the more likely voters will be receptive to political messages. In the same vein, Henneberg and Chen (2008) supported by Austin et al. (2008) observe that most political candidates and their campaign managers believe that when more celebrities endorse politicians, there is a higher possibility of the politicians winning the election. This view was also supported by Austin et al. (2008) who note that the celebrity-endorsed campaigns seemed to attract positive reception of the messages.

Garthwaite and Moore (2008) also made an attempt to estimate the effect of celebrity endorsement on political outcomes. The researchers assessed the impact of Oprah Winfrey's endorsement of Barack Obama prior to the 2008 democratic presidential primaries to confirm that Winfrey's endorsement had significant effects on Obama's election outcomes. Her involvement increased the number of votes received by Obama, as well as the overall level of voter participation. This might be due to the fact that the research went beyond young voters, as this study did, to survey a wider and more inclusive group of people. These assertions point to the fact that adult voting behaviour can be swayed in favour of politicians who are backed by celebrities. But does the same always hold true for young adults and college students? 
This is the version of the article accepted for publication in Journal of African Media Studies published by Intellect doi: 10.1386/jams.9.3.487 1

Accepted version downloaded from SOAS Research Online: http://eprints.soas.ac.uk/32045

Jackson and Darrow (2005) established that celebrities had some influence on young adults, with respect to the reception of political statements made by celebrities. These authors conducted research on the attitude of voters and discovered that young voters were easily affected by the participation of celebrities in politics. Payne, Hanlon and Twomey (2007) as well as Austin et al. (2008) suggest that celebrity endorsements improved the voting intentions of young adults. For Austin et al., celebrities have the power to persuade and educate young voters, and also get them to participate in the voting exercise. This is not surprising given that scholars like Burton and Netemeyer (1992), Brown, Basil and Bocarnea (2003) and Jackson and Darrow (2005) affirm that young people hold some celebrities in high esteem and participate in a deep fan culture around celebrities. So, for young people, celebrities are not only famous entertainers, they are also role models. Nownes (2012) equally and strongly established that athletes and movie stars' implicit endorsements (i.e. by way of financial support) also affected the view of young voters' regarding the endorsed parties. Austin et al. (2008) found that the celebrity-endorsed get-out-the-vote campaigns influenced young voters to join election campaigns. These findings collectively suggest that with celebrity endorsements, political aspirants gain traction during their campaigns, which translates to higher votes by the young and old. However, the enthusiasm shown by young adults and older voters during election campaigns and rallies is not always shared by all.

The widely-held belief that celebrities can influence public vote through their participation in causes seems to be at variance with some other studies. McCracken (1989) observed that it is easier for the audience to trust a celebrity when it comes to the general marketing of products than when it involves voting for a political aspirant. Although Erdogan (1999) points out that source credibility, a vital factor in the celebrity selection process, has been proven to have a direct and significant effect on attitudinal and behavioral intentions, he also postulates that source credibility is not the only factor to be considered in effective persuasion of an audience. The concept does not give a well-grounded explanation of other essential factors that might influence attitude and behaviour. For instance, he suggests that if the audience has a warm disposition to the message being conveyed, a low-credible source can be more believable than a high-credible source. West and Orman (2002) criticise the celebrity and politics binary, adding that celebrities do not possess the knowledge or political experience to speak on political issues. They affirm that serious political issues become trivialised in the attempt to elevate celebrities to 'philosopher-celebrities' (p. 118). In a 2007 USA Today/Gallup Poll, more than six in ten adults said that celebrity endorsements were not important in deciding the victory of any political aspirant, and ten percent claimed that Oprah Winfrey's support made them less likely to support Barack Obama (Moore, 2007). This position is upheld by Baum (2006) and Ridley (2010) when they illustrate how voters do not necessarily trust celebrities as they would political analysts when it came to voting influences during elections. In addition, Wood and Herbst (2007) established that, celebrity endorsement of political candidates had little or no effect on the voting decisions of first-time voters compared to the influence of family and friends. When it comes to celebrities' credibility on political issues, there were more doubts than trust. 
A similar point was made by Shipman (2010), who reports that celebrity endorsements disincline college students from voting for the endorsed candidate. Such campaign strategies actually make them like the candidates less. Brubaker (2011) also discovered that celebrity endorsements of in-group political candidates did not affect the attitude of college-aged voters because they already supported the endorsed politician and distanced themselves from celebrity endorsements of out-group political candidates. Further, O'Regan's (2012) study examined if young, college-aged adults listen to celebrity endorsements of political candidates and issues, and how they perceive celebrities drawing attention to politics. She concludes that young adults are less likely to trust the celebrity endorsement of a candidate or issue, and are more likely to trust the endorsement of someone active in politics, such as another politician or interest group, or someone they know personally. Young adults also perceive celebrities to be influential in drawing attention to a political issue or candidate. But their perceptions of the celebrities do not influence their votes. This implies that the celebrities may not really have the sway they are perceived to possess in influencing voting behaviour. However, they seem to be capable of creating overwhelming awareness and drawing attention to the messages being communicated.

According to Chou (2015), voters would naturally vote candidates they are comfortable with whether or not they are endorsed by celebrities. O'Regan (2014) provided some possible reasons for the differing effects of celebrity endorsement of politicians to include voters' ethnicity, gender and the importance of the issues promoted by the celebrities. From the debates on the perceived effects of political celebrity endorsement, there appears to be no consensus on the nature or depth of celebrity influence on young adults, when it comes to politics and elections. It remains to be empirically tested within a specific African context such as Lagos to determine the degrees of influence, if any.

\section{Political celebrity endorsements and campaigns in Nigeria}

The celebrated African writer, Chinua Achebe, is arguably the first to endorse politicians and political causes in the Nigerian society (Achebe, 2012) in the 1960s when he was the emissary for the Biafran agenda. Later in the 1980s, Chika Okpalla (Zebrudaya) and some other cast of the television drama, The New Masquerade, promoted consumer goods by PZ Industries. A football star, John Chidozie, was also known for his endorsements of Lifebuoy soap. These early examples show that celebrity endorsement is not a new phenomenon in Nigeria. In recent times, it has taken various forms mainly through crusades, concerts, campaigns and social media platforms.

Media celebrities demonstrated huge support for the political aspirants of the 2011 and especially the 2015 elections. During the February 2011 voter's registration process in Nigeria, there were non-partisan crusades by celebrities aimed at encouraging young adults to register and vote. One of such was 'Our Time Initiative and Concert', which was launched by Oladapo Daniel Oyebanjo, popularly known as “D’banj” along with other music artistes. This 
campaign educated voters on their civic rights and responsibilities primarily through concerts in the six geopolitical zones in Nigeria. Other music artistes like Tuface, PSquare, Wizkid, Timi Dakolo and Timaya performed at the concerts. The audience only had to attend the concerts with their voter's registration cards as passes. The 'Enough is Enough Nigeria' (EiE) campaign was another promotion of politics among celebrities using social media. The promoters were mostly Nollywood celebrities like Kate Henshaw, Omotola Jalade-Ekeinde and Omoni Oboli and music artistes such as Tuface Idibia, MI and TY Bello. While the campaign did not support any political party, it promoted the R.S.V.P (register, select, vote and protect) slogan (Itiri, 2015). The EiE project was also extended to the 2015 general election.

Other campaigns led by Tuface Idibia and Kanayo O. Kanayo were the 'Vote Not Fight' and 'No BAGA' respectively. These projects cautioned youth against violence during the 2015 general elections. They advocated peaceful participation in the electoral process and nonviolent transition to power and social change. They also urged politicians to act with caution. Other celebrities involved in the campaigns were Nkem Owoh, Patience Ozokwor and Osita Iheme.

Celebrities promoted the candidacy of the incumbent president, Goodluck Jonathan, not only by showing up at political rallies but also through their social media following. Mike Ezuruonye, a Nollywood actor, shared a picture of himself and the Presidential Candidate, Goodluck Jonathan, on his Instagram page and was also visible in a political rally. Ibinabo Fiberesima took to Instagram and announced support for the incumbent using his initials 'GEJ till 2019'. Omoni Oboli also showed her support on social media with a post that read: 'My president! Goodluck Ebele Jonathan! 2015! \#voteyouthempowerment \#2015till2019...' Nollywood actress, Foluke Daramola's husband, Kayode Salako posted a picture of the couple on social media announcing their endorsement of the APC Presidential Candidate with the caption: 'Stay calm, vote Buhari in. Let's change Nigeria".

Another campaign strategy adopted by media celebrities was music. For instance, Olamide recorded two singles to show his support for the APC party. The songs were titled APC Ese (thank you) and The change we want.

Award-winning musician - Bisade Ologunde (Lagbaja) - openly showed his support for the APC presidential candidate. After receiving his permanent voter's card, he posted a picture of himself on Facebook and stated that President Goodluck Jonathan will not succeed in his second term bid. Other prominent artistes also recorded campaign songs for Akinwunmi Ambode, the APC gubernatorial candidate of Lagos, titled Gbabe (Accept it) and Gbo Gbo Wa La Leko (We all own Lagos). It is one thing to have popular musicians promote a political cause and yet another to convert those efforts to actual votes for the politicians favoured by the songs.

Questions have been asked about the factors that propel endorsement of party candidates by celebrities. There are a number of reasons why celebrities decide to endorse political 
candidates. It could be that they are disappointed with the way the government is run by the incumbent politicians and believe they can influence voters to support the candidates they endorse. Clarion Chukwurah, a well-known Nollywood actress, stated that Nigerian celebrities are venturing into politics for monetary benefits (Ikeh, 2014). It is also possible that the celebrities supported President Goodluck Jonathan because of the funds he contributed to the entertainment industry. In 2010 and 2013, Jonathan announced a creative industries' intervention fund of $\$ 200$ million and $\$ 3$ billion respectively. The intervention was intended to open up corporate investment opportunities for the industries, and support practitioners in boosting the film, music and allied industries. The management of the funds was the responsibility of the Bank of Industry (BOI), the Nigerian Export-Import Bank (NEXIM) and the Ministry of Finance. Controversies over disbursement strategies and stringent distribution mechanisms dominated the media, with film practitioners expressing intense displeasure over their inability to access the funds. But the presidential announcement had drawn popular goodwill to Jonathan and made him the preferred candidate for media celebrities.

To the various factors put forward as the rationale for employing celebrity endorsement of politicians in spite of growing doubts, we add the following obtained from Steve Ayorinde, Chude Jideonwo and Uti Nwachukwu.

\section{Factors that justify the adoption of celebrity endorsement as a campaign strategy}

In spite of the seemingly increasing distrust of celebrity endorsements of politicians among the electorate, campaign managers continue adopting it as a strategy. Previous success stories in the use of celebrity endorsement accounted for its deployment in the 2015 elections. According to Ayorinde, 'celebrity endorsement as a campaign strategy has been used in 2007 and 2011, though not the way it is done now (2015), and it was quite effective' (S. Ayorinde, personal communication, April 15, 2016). He specifically mentioned that in 1993, Tony Okoroji, president of Performing Musicians Association of Nigeria (PMAN) assembled a team of musicians, who showed their support for Moshood Abiola during his election campaign. He also stated that in 2007, some celebrities endorsed Jimi Agbaje, one of the gubernatorial candidates for Lagos, during his election campaign. This shows that celebrity endorsement of political candidates in the past had probably yielded success in creating awareness for the politician which is why the campaign managers considered it effective. Jideonwo said that celebrity endorsements make political candidates more popular and that if he had the means, he would adopt the celebrity strategy because 'it is a useful strategy that leads to name recall' (C. Jideonwo, personal communication, February 25, 2017). Ayorinde's and Jideonwo's assertions are in consonance with Street's (2002) insistence on celebrity power as legitimization and effectiveness.

A second factor is the perceived alignment of the celebrity with the vision of the political candidate. Some celebrities seem to have endorsed politicians because they believed in the 
vision expressed by such candidates. Ayorinde stated that celebrity endorsers were people who shared the aspirations of the party candidate and could effectively spread the campaign message through their popularity and large social media followership. The general belief is that celebrities are not knowledgeable in politics (Baum, 2006; West and Orman, 2012) and so to create the desired effect, the campaign managers decided to use celebrities that were politically articulate. He said 'we were looking for celebrities that will key into our dreams, visions and aspirations. Celebrities that had shown traits of being politically inclined and who were progressively minded' (S.Ayorinde, personal communication, April 15, 2016). In addition, Uti Nwachukwu claimed that he supported Ambode Akinwunmi because the latter struck him as a dedicated politician, "my first impression of him like I said when I endorsed him was someone who is ready to work" (U.Nwachukwu, personal communication, April 28, 2016). It is unclear, however, how celebrities who key into politicians' visions are identified and employed since quite often, such visions are not clearly articulated beyond publicity materials that splash photographs and slogans. Both Ayorinde's and Nwachukwu's comments portray a vagueness of ideas and unspecified dreams, visions or aspirations. This further suggests that there might be reasons other than alignment with an aspirant's political vision.

One contentious reason for the use of celebrity endorsements in election campaigns is attached to the financial benefits which celebrities are thought to obtain from such promotions. In contrast to the common belief in supporting politicians for money, an endorser summed up the views of several other celebrities by stating that he did not receive any monetary benefit for supporting the APC gubernatorial aspirant, Akinwunmi Ambode. Confidence in the politician to effect positive change rather than material gain spurred his action. He said, 'I did not receive any money to endorse Akinwunmi Ambode' (U.Nwachukwu, personal communication, April 28, 2016). Popular Nollywood actress, Omoni Oboli, made a similar statement. While celebrities forego personal payments for endorsing politicians, it is evident that they do so in the hope of attracting some improvement in their trade. Nwachukwu points this out clearly when he stated,

entertainers are human beings like everybody. If they want something, they say it especially when it affects everybody... so yes...some entertainers ...want this person to win this election so that things will be better for us all. (U.Nwachukwu, personal communication, April 28, 2016)

Some of the celebrities have been supported by politicians and so they turn around to lend their support when the politicians are running for public office. For instance, Nollywood celebrities endorsed Goodluck Jonathan because of his support to the entertainment industry. During their endorsements, Rita Dominic and Ramsey Nouah said they supported Goodluck Jonathan because the entertainment industry benefitted from his administration. Further, Ayorinde stated that,

Governor Ambode is very much involved in art and entertainment and had assisted a few artistes in growing their career so he already had an enormous 
This is the version of the article accepted for publication in Journal of African Media Studies published by Intellect doi: 10.1386/jams.9.3.487 1

Accepted version downloaded from SOAS Research Online: http://eprints.soas.ac.uk/32045

social capital on the part of the entertainment industry and these people were very eager to support him. (S.Ayorinde, personal communication, April 15, 2016)

A film producer, Omoni Oboli, was granted the rare opportunity of a film premiere in the presidential villa while Goodluck Jonathan was president, so it was not difficult to endorse him during his electoral campaign.

A fourth reason why campaign managers would enlist celebrities is that such film and music stars enjoy huge popularity among the youth and women; and they have been described as role models for young adults (Brown, Basil \& Bocarnea, 2003). Ayorinde stated that the campaign team believed that the messages passed through the celebrities to the public would resonate in the minds of people especially women and the youth. He said 'the message was general but again we knew that sixty five percent of those we were targeting were the youths and women' (S.Ayorinde, personal communication, April 15, 2016). One of the major reasons as stated by Ayorinde is that the party members were mostly men and the members could easily reach out to their fellow men so men were not the primary targets of the celebrities. The campaign team aimed at reaching women and youths, who they felt could be influenced by celebrities to vote.

A rather obvious but previously unexplored reason for political celebrity endorsement in 2015 was the visibility on social media where stars engage with their fans. A lot of election campaigning was done on social media and owing to the massive followership enjoyed by celebrities, campaign managers would leverage on that to reach their fans. Numerous campaign and endorsement videos were uploaded on YouTube. Jideonwo state, 'For Ambode, it created pop culture so the songs and pictures on social media made him more popular. It made people feel good towards him' (C. Jideonwo, personal communication, February 25, 2017). Celebrities who are active on social media were probably considered a great channel to communicate the campaign message. A Scarborough study in 2013 revealed that voters who follow celebrities find out much of their information from social networking sites, and these voters are influenced by what is presented on such sites. Voters influenced by celebrities are more likely to take to Twitter, Facebook and other social sites to access news and information, find out information about services, and comment on brands (Scarborough, 2013). The campaign managers wanted celebrities who could communicate to the public through their large followership on social media platforms and possibly influence the attitude of the voters. The interviewer gathered that the aim of using celebrities was because they were popular, had enormous followership on social media platforms. An interviewee affirmed, 'We are talking about celebrities with nothing less than ... eight hundred thousand, even a million followers on Twitter and could reach a large audience' (S.Ayorinde, personal communication, April 15, 2016)

Celebrity-turned-politicians galvanize support among fellow celebrities. Politics requires social networks, and celebrities seem to have large networks both online and offline. Once a 
cause requires the attention of a celebrity, that celebrity can utilize his social network to recruit other celebrities (Street, 2002). For instance, John Kerry's campaign in the United States, gained the support of Bruce Springsteen (a popular American musician) during the 2004 campaign. Through Springsteen's ties, other celebrities were recruited. The interviewee seems to support this opinion when he stated that it was not difficult to get the support of other celebrities through the efforts of Richard Mofe-Damijo and Desmond Elliot, two film stars who are now prominent politicians in different constituencies. In his words,

[...] we already had a popular actor Desmond Elliot who was running to become a member of the House of Assembly. He was an inner member of the campaign team for Governor Akinwunmi Ambode, and so he brought in a few of his colleagues. (S.Ayorinde, personal communication, April 15, 2016)

One of the celebrities claimed, 'I knew a lot of people including my colleagues will see the messages I was posting so I was hoping to inspire them' (U.Nwachukwu, personal communication, April 28, 2016). Such ripple effects attract not only other celebrities but also the media, the public and policy makers as affirmed by Duncombe (2007). It confers an ambassadorial status on the celebrities hope to use the media attention to influence election outcomes.

A perceived ability of celebrities to thrill audiences at campaign rallies, thereby influence voting decisions was another reason given by Ayorinde and Nwachukwu. Celebrities have been shown to bring visibility to election campaigns. Their participation can make a conservative political candidate seem more hip (Lilywfu, 2013) and bring excitement to the election campaign. This conforms to Ayorinde's views when he said that the celebrities his team worked with excited the audience during the campaign rallies. He specifically mentioned how Daddy Showkey, a popular musician, thrilled the crowd at Ajegunle, a Lagos slum, during one of their campaign rallies. Young people will attend a political event like campaign rallies simply because a celebrity they admire is performing or speaking (Ellis, 2012). Messages communicated through the celebrities will likely be better received, and possibly have a persuasive effect. Ayorinde authoritatively affirmed that to a great extent, celebrity endorsement of Akinwunmi Ambode influenced voting decisions among the general public and young voters in particular. He was of the opinion that people listened to the celebrities and must have been influenced to vote for Akinwunmi Ambode because celebrities that they admired and believed in said 'vote for him, I am also voting for him'. The campaign manager was almost dogmatic in stating that celebrity endorsement was a good campaign strategy because there was positive response on social media and at the polls. In his opinion, the celebrity endorsement strategy adopted by his party in the election campaign yielded significant outcomes. He said,

Celebrity endorsement played a great part. I can say it won more than a quarter of the total votes... and from the results at the polls, we believe it was 
This is the version of the article accepted for publication in Journal of African Media Studies published by Intellect doi: 10.1386/jams.9.3.487 1

Accepted version downloaded from SOAS Research Online: http://eprints.soas.ac.uk/32045

an effective campaign strategy. (S. Ayorinde, personal communication, April $15,2016)$

Having established some of the key factors that led to the use of celebrity endorsement of political aspirants by campaign teams, attention is now turned to if and how it influenced the voting behaviour of young voters during the 2015 elections. The quantitative analysis below responds to the second research question which interrogates the young adults themselves and contrasts their responses with those campaign managers and celebrities.

\section{Descriptive survey findings}

A total of 375 young adults randomly selected from the college premises and comprising 214 females, 161 male students participated in the study. A 17-item questionnaire was administered to the students. Although the academic qualification is not a key variable in the study, the table below shows the distribution of the respondents by age and academic qualification, thus revealing the majority as National Diploma (ND) students. The Higher National Diploma (HND) and the post-HND students are in the minority. About a third (142) of them claimed familiarity with a famous Nollywood actor and cross-over politician, Desmond Elliot, as an endorser and only 56 respondents were aware of popular musician, Olamide's, endorsements of the APC political candidates.

Table 1: Academic Qualification and Age of Respondents

\begin{tabular}{|c|c|c|c|c|c|}
\hline & & \multicolumn{3}{|c|}{ Age of the Respondents } & \multirow[t]{2}{*}{ Total } \\
\hline & & 18-20years & 21-23years & 24-25years & \\
\hline \multirow{3}{*}{$\begin{array}{l}\text { Academic Qualification } \\
\text { of the Respondents }\end{array}$} & ND & 100 & 138 & 69 & 307 \\
\hline & HND & 4 & 19 & 16 & 39 \\
\hline & Post HND & 2 & 6 & 21 & 29 \\
\hline \multicolumn{2}{|l|}{ Total } & 106 & 163 & 106 & 375 \\
\hline
\end{tabular}

The fact of fandom among the college respondents of the study was not in doubt. About twothirds (229) of them claimed that they are fans of Nollywood celebrities particularly Desmond Elliot, Funke Akindele, Toyin Aimakhu, Ini Edo and Patience Ozokwor. More than two-thirds (274) of the respondents admitted to being fans of music artistes with the top five being Olamide, MI, Flavour, Banky W and Yemi Alade. The celebrities enjoy a huge following among young adults as Burton and Netemeyer (1992); Brown, Basil and Bocarnea, (2003) as well as Jackson and Darrow (2005) pointed out. As highlighted at the beginning of 
This is the version of the article accepted for publication in Journal of African Media Studies published by Intellect doi: 10.1386/jams.9.3.487 1

Accepted version downloaded from SOAS Research Online: http://eprints.soas.ac.uk/32045

this paper, these authors' assertions justify the rationale for examining how political celebrity endorsements influence the voting behaviour of young adults.

Table 2: Celebrity endorsement and respondents' views

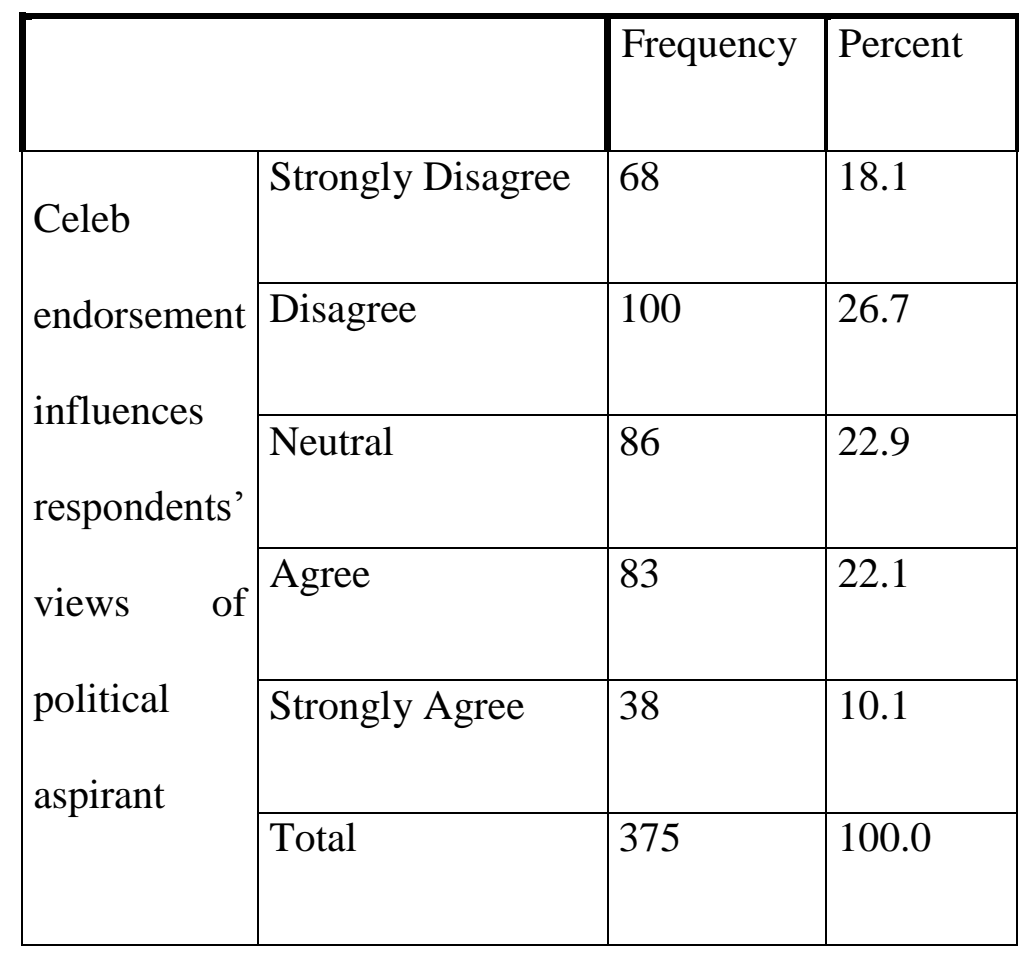

Table 3: Attractiveness of a celebrity endorser

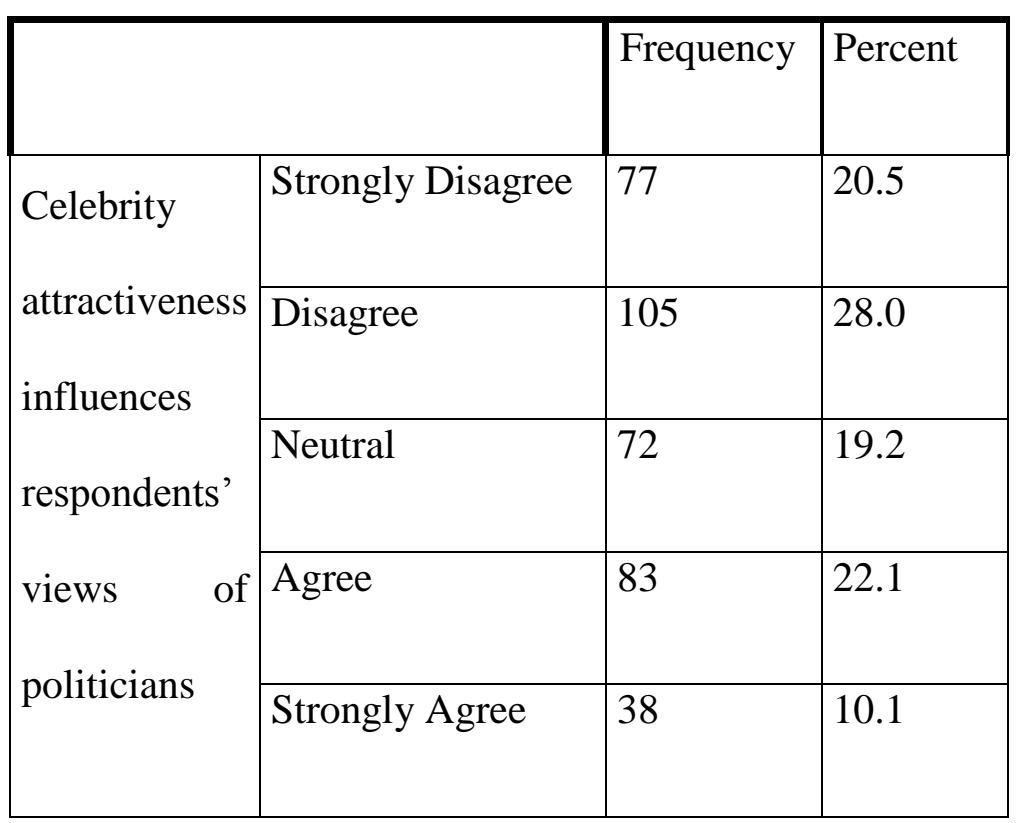


This is the version of the article accepted for publication in Journal of African Media Studies published by Intellect doi: 10.1386/jams.9.3.487 1

Accepted version downloaded from SOAS Research Online: http://eprints.soas.ac.uk/32045

\begin{tabular}{|l|l|l|l|}
\hline & Total & 375 & 100.0 \\
\hline
\end{tabular}

Table 4: Trustworthiness of a celebrity endorser

\begin{tabular}{|c|c|c|c|}
\hline & & Frequency & Percent \\
\hline & Strongly Disagree & 75 & 20.0 \\
\hline & Disagree & 106 & 28.3 \\
\hline influences & Neutral & 97 & 25.9 \\
\hline respondents' & Agree & 69 & 18.4 \\
\hline views & & & \\
\hline politician & Strongly Agree & 28 & 7.5 \\
\hline & Total & 375 & 100.0 \\
\hline
\end{tabular}

Table 5: Celebrity endorsement and respondents' voting behaviour

\begin{tabular}{|l|l|l|l|}
\hline \multicolumn{2}{|l|}{} & Frequency & Percent \\
\hline \multirow{4}{*}{$\begin{array}{l}\text { Celeb endorsement of } \\
\text { politician influences } \\
\text { respondents'votes }\end{array}$} & $\begin{array}{l}\text { Strongly } \\
\text { Disagree }\end{array}$ & 106 & 28.3 \\
\cline { 2 - 5 } & Disagree & 114 & 30.4 \\
\cline { 2 - 4 } & Neutral & 83 & 22.1 \\
\cline { 2 - 5 } & $\begin{array}{l}\text { Agree } \\
\text { Agrongly }\end{array}$ & 50 & 13.3 \\
\hline
\end{tabular}


This is the version of the article accepted for publication in Journal of African Media Studies published by Intellect doi: 10.1386/jams.9.3.487 1

Accepted version downloaded from SOAS Research Online: http://eprints.soas.ac.uk/32045

\begin{tabular}{|l|l|l|l|}
\hline & Total & 375 & 100.0 \\
\hline
\end{tabular}

Table 6: Support for political party and respondent's voting decision

\begin{tabular}{|l|l|l|l|}
\hline \multicolumn{2}{|l|}{} & Frequency & Percent \\
\hline \multirow{4}{*}{$\begin{array}{l}\text { Support for } \\
\text { political party }\end{array}$} & Strongly Disagree & 43 & 11.5 \\
\cline { 2 - 4 } NOT celebrity & Disagree & 70 & 18.7 \\
\cline { 2 - 4 } endorsement & Agree & 61 & 16.3 \\
\cline { 2 - 4 } & Strongly Agree & 75 & \\
\cline { 2 - 4 } & & 126 & 33.6 \\
\cline { 2 - 4 } & Total & 375 & 100.0 \\
\hline
\end{tabular}

Table 7: Celebrity credibility versus politician credibility

\begin{tabular}{|l|l|l|l|}
\hline \multicolumn{2}{|c|}{} & Frequency & Percent \\
\hline \multirow{2}{*}{$\begin{array}{l}\text { Respondents } \\
\text { believed }\end{array}$} & Strongly Disagree & 98 & 26.1 \\
\cline { 2 - 4 } celebrities & Disagree & 89 & 23.7 \\
\cline { 2 - 4 } more than & Neutral & 97 & 25.9 \\
\cline { 2 - 4 } politicians & Agree & 67 & 17.9 \\
\hline
\end{tabular}


This is the version of the article accepted for publication in Journal of African Media Studies published by Intellect doi: 10.1386/jams.9.3.487 1

Accepted version downloaded from SOAS Research Online: http://eprints.soas.ac.uk/32045

\begin{tabular}{|l|l|l|l|}
\hline \multirow{2}{*}{ on political } & Strongly Agree & 24 & 6.4 \\
\cline { 2 - 4 } & Total & 375 & 100.0 \\
\hline
\end{tabular}

Table 8: Celebrity credibility versus family and friends credibility

\begin{tabular}{|l|l|l|l|}
\hline \multicolumn{2}{|c|}{} & Frequency & Percent \\
\hline \multirow{2}{*}{$\begin{array}{l}\text { Respondents } \\
\text { believed family } \\
\text { members/friends } \\
\text { more than } \\
\text { celebrities on } \\
\text { political issues. }\end{array}$} & Strongly Disagree & 37 & 9.9 \\
\cline { 2 - 4 } & Disagree & 68 & 18.1 \\
\cline { 2 - 4 } & Strongly Agree & 69 & 23.7 \\
\cline { 2 - 5 } & Total & 89 & 18.4 \\
\hline
\end{tabular}

Table 9: Celebrity endorsement influence on other young voters

\begin{tabular}{|l|l|l|l|}
\hline \multicolumn{2}{|c|}{} & Frequency & Percent \\
\hline \multirow{2}{*}{$\begin{array}{l}\text { Celebrity } \\
\text { endorsement } \\
\text { influence on } \\
\text { other young } \\
\text { voters }\end{array}$} & Strongly Disagree & 40 & 10.7 \\
\cline { 2 - 4 } & Disagree & 55 & 14.7 \\
\cline { 2 - 4 } & Neutral & 71 & 18.9 \\
\cline { 2 - 4 } & Strongly Agree & 67 & 17.9 \\
\cline { 2 - 4 } & Total & 375 & 100.0 \\
\hline
\end{tabular}


This is the version of the article accepted for publication in Journal of African Media Studies published by Intellect doi: 10.1386/jams.9.3.487 1

Accepted version downloaded from SOAS Research Online: http://eprints.soas.ac.uk/32045

Table 10: Celebrity endorsement as attention booster

\begin{tabular}{|c|c|c|c|}
\hline & & Frequency & Percent \\
\hline & Strongly Disagree & 32 & 8.5 \\
\hline endorsement & Disagree & 48 & 12.8 \\
\hline & Neutral & 84 & 22.4 \\
\hline political & Agree & 158 & 42.1 \\
\hline issues or & Strongly Agree & 53 & 14.1 \\
\hline & Total & 375 & 100.0 \\
\hline
\end{tabular}

\section{Discussion}

This study aimed to determine the voting behaviour of voters aged 18 to 25 during the 2015 elections as influenced by celebrity endorsements of political aspirants.

Majority of the respondents admitted to being fans of celebrities as already reported above. From Table 2, it can be seen that celebrity endorsement does influence young voters' views of the politicians who campaigned during the 2015 elections. Although 168 of them disagreed with the idea that their views and perceptions of political aspirants were influenced by celebrity endorsements, another 121 agreed to being so influenced. These findings are consistent with previous works reviewed above particularly those of Jackson and Darrow (2005), Austin et al (2008), Garthwaite and Moore (2008) and Brubaker (2011). The fact that more respondents denied influence does not repudiate the impact of celebrities' influence on voters especially when contrasted with the details of Tables 9 and 10 above. Brubaker explored the concept of third-person effects theory in an attempt to explain how people believe that celebrity endorsements influence others but not themselves (see Table 9).

There is no strong evidence from the findings of this study to support the denial of celebrity influence on oneself (as seen in Table 5) other than self reporting. We therefore argue that, if 209 young respondents affirm that celebrity endorsement influences the voting behaviour of other young voters, not themselves who belong to the same youth category, and only 95 disagree with the idea, then there is sufficient evidence in favour of political celebrity endorsement on the one hand. On the other hand, celebrity endorsement might motivate 
young people to participate in rallies and make them more aware of political causes, but not influence them to vote. Why would Steve Ayorinde, a campaign manager employ celebrities as ambassadors for political candidates if the effort held no prospects? As Brubaker (2011) pointed out, 'Not only are celebrities eager to get involved with political causes and candidates, but causes are anxious to have celebrity representation...A celebrity face makes that particular candidate or cause stand out in a sea of political causes' (p. 7). Besides, Garthwaite and Moore (2008) suggest that if celebrity endorsement of products works favourably, why should we not expect it to work in the political realm? These questions might also raise some doubts about young people's self reporting which seeks to promote an ideal or expected image of oneself rather than the actual image. It is quite possible that young voters who claim that celebrity endorsement fails to influence them do not want to be perceived as being gullible or undiscerning in matters such as elections and politics. What is clear about the data is the lack of uniformity, also evident in the literature, in asserting that celebrity endorsements influence votes. This dichotomy suggests that celebrity endorsement in addition to other election campaign strategies are the guarantee for electoral victory. Jideonwo said emphatically,

[celebrity endorsement] is a useful strategy but it cannot be the primary strategy of any campaign. It is a supporting strategy but cannot be the thrust of any campaign. It does not hurt but it is not what convinces voters to vote. (C. Jideonwo, personal communication, February 25, 2017)

In line with the above and as can be gleaned from Figure10, celebrity endorsement is an attention booster. Respondents of this study agree that if you put a celebrity in front of a politician, that politician will be much more visible. Again, this supports extant literature on the subject, not only for consumer goods and social causes, but also for election campaigns. The respondents affirmed that celebrity endorsement draws attention to political issues or candidates. This finding is consistent with the views of Jackson and Darrow (2005), who established that celebrities had some influence on young adults; with respect to the reception of political statements and positions made by celebrities. Most of the respondents also agreed with the idea that celebrities are effective at conveying political messages to the general public. This finding is similar to the postulation of the source credibility theory which postulates that the effectiveness of the message being conveyed largely depends on the source. It is so in this case because of the huge followership, fame enjoyed by the celebrities.

More than a third of the respondents affirmed that their views of a celebrity-endorsed politician were not influenced favourably by the attractiveness, trustworthiness (Tables 3 and 4) or likeability of the celebrity. This seems to suggest that there comes a time when youth perceptions of attractiveness and trustworthiness of celebrities are kept out of their impressions of politicians however highly regarded such celebrities might be. Physical attractiveness and charisma found no place in the persuasion of the youth who participated in this study. The concept of trustworthiness seems to pose additional doubts in the minds of voters, many of whom have no personal dealings with the celebrities. They see them when 
they act or sing, when they follow them on social media or read the interviews they routinely grant. Although details of the celebrities' personal lives may be known by virtue of their popularity, that appears to be insufficient in determining who a trustworthy political endorser might be. When contrasted with comments of Ramsey Nouah and Omoni Oboli who endorsed Goodluck Jonathan because of the funds he made available to the entertainment industries, it becomes clear that celebrity trustworthiness is an ambiguous concept which will not compel the votes.

More than half of the respondents (58.7\%) did not vote for the candidates based on the endorsement of a celebrity during the 2015 elections (Table 5). This means that even though they admired the celebrities who endorsed the party candidates, the endorsement did not influence their voting decisions. A third of the respondents seemed to identify more with the political party than with the gubernatorial or presidential candidate himself (Table 6). This shifts the attention from the celebrities to other campaign strategies including the contenders' presentation of themselves rather than their support by Nollywood stars or their musician counterparts.

This study discovered that young adults accept information more from other sources like friends and family (Brubaker's in-groups), rather than from celebrities (Tables 7 and 8). This could be due to the fact that some young adults believe celebrities are not well-versed in political and public affairs or governance. This result is similar to the findings of O'Regan (2012), who conducted a research in 2014 and found that young adults are more receptive to messages from sources like family and friends than from any other group of people. She aslo found that young college-aged adults would readily trust the endorsements of other active politicians, interest groups or other informed people who are not celebrities. Our finding also corroborates those of Wood and Herbst (2007) and Shipman (2010). For those scholars, young people had more doubts than trust for political celebrity endorsements.

\section{Conclusion}

This study examined the celebrity endorsement of politicians and its effects on college students in the context of an African city, Lagos. It was driven by two key research questions. We were interested in documenting the factors that justify the use of political celebrity endorsement as a campaign strategy in 2015 given that the literature reviewed showed an increase in scholarship for celebrity endorsement for consumer goods but a paucity for politics in Africa. Although voters would express doubts in being influenced to vote by celebrities, scholars and campaign managers have reason to think that the strategy achieves partial success in promoting, sensitizing and activating discussions about who to vote for. Our findings revealed that campaign managers would use the strategy again in the confidence that it achieves their objectives. 
From the engagement with the second research question which aimed at ascertaining if celebrity endorsement of party candidates affected the voting behaviour of young voters during the 2015 elections, it is clear that the evidence supports and is supported by existing literature. Celebrity endorsement is not an isolated success strategy for electoral campaigns. Obviously, it does have its merits and utility, but it also has questions which other strategies are better able to respond to. The findings indicate that in spite of youth admiration of celebrities, self-reported voting behaviour in Lagos was not influenced in favour of the endorsed.

This study contributes to the larger body of work on celebrity studies which is currently located within the broad discipline of media and communication studies. Most studies on celebrities and endorsements focus on product and commercially viable brands within advertising and marketing communication disciplines, but this study has devoted attention to the study of celebrities, celebrity culture and endorsements within the political arena.

\section{References}

Achebe, C. (2012), 'There was a country: A personal history of Biafra', London: Penguin Books.

Atkin, C. and Block, M. (1983), 'Effectiveness of celebrity endorsers', Journal of Advertising Research, 23:1, pp. 57-61. 
This is the version of the article accepted for publication in Journal of African Media Studies published by Intellect doi: 10.1386/jams.9.3.487 1

Accepted version downloaded from SOAS Research Online: http://eprints.soas.ac.uk/32045

Austin, E., Vord, R., Pinkleton, B. and Epstein, E. (2008), 'Celebrity endorsements and their potential to motivate young voters', Mass Communication and Society, 11:4, pp. 420-36.

Baum, M. (2006), 'The Oprah effect: How soft news helps inattentive citizens vote consistently', The Journal of Politics, 68:4, pp. 946-959.

Belch, G. E. and Belch, M. A. (2001), Advertising and Promotion: An Integrated Marketing Communications Perspective, New York: McGraw Hill.

Brown,W., Basil, M. and Bocarnea, M. (2003), 'Social influence of an international celebrity: Responses to the death of Princess Diana', Journal of Communication, 53:4, pp. 587-605.

Brubaker, J. (2011), 'It doesn't affect my vote: Third-person effects of celebrity endorsement on college voters in the 2004 and 2008 Presidential Elections', American Communication Journal, 13:2, pp. 4-22.

Burton, S. and Netemeyer, R. (1992), 'The effect of enduring, situational and response involvement on preference stability in the context of voting behavior', Psychology \& Marketing, 9:2, pp. 143-57.

Chou, H. (2015), 'Celebrity political endorsement effects: A perspective on the social distance of political parties', International Journal of Communication, 9, pp. 523-46.

Duncombe, S. (2007), 'Taking celebrity seriously', The Nation, 11 October, pp. 22-24.

Durante, T. (2012), 'Famous friends: The list of 194 celebrities the Obama campaign hopes will help with the presidents re-election', Mail Online, 12 January, http://www.dailymail.co.uk/news/article-2085817/The-list-194-celebrities-Barack-Obamascampaign-hopes-help-presidents-election.html. Accessed 4 February 2016.

Durojaiye, K. (2015), Kunledurojaiye, 15 November, Agina - Celebrity endorsement of political aspirants.doc. Accessed 4 February 2016.

EIE (n.d.), 'Enough is enough coalition', http://eie.ng/rsvp/. Accessed 16 February 2016.

Ekeleme, M. (2015), 'Celebrities and their power of influence', Champion News, 30 January, http://www.championnews.com.ng/celebrities-and-their-power-of-influence/. Accessed 20 November 2015.

Ellis, C. B. (2012), 'Celebrity Endorsement in Politics. Talking Politics', 2 November, https://talkingpoliticsjomc.wordpress.com/2012/11/02/celebrity-endorsement-in-politics/.

Accessed 30 May 2016.

Erdogan, B. (1999), 'Celebrity endorsement: A literature review', Journal of Marketing Management, 15:4, pp. 291-314. 
This is the version of the article accepted for publication in Journal of African Media Studies published by Intellect doi: 10.1386/jams.9.3.487 1

Accepted version downloaded from SOAS Research Online: http://eprints.soas.ac.uk/32045

Garthwaite, C. and Moore, T. (2008), 'The role of celebrity endorsements in politics: Oprah, Obama, and the 2008 democratic primary', http://www.stat.columbia.edu/ gelman/stuff_for_blog/celebrityendorsements_garthwaitemoo re.pdf. Accessed 2 February 2016.

Henneberg, S. and Chen, Y. (2008), 'Celebrity political endorsement: Campaign management for the Taipei City councillor election', Journal of Political Marketing, 6:4, pp. 1-31.

Ikeh, C. (2014), 'Why Clarion Chukwurah is against entertainers going into politics', thenet.ng., Nigerian Entertainment Today, 17 October,s http://thenet.ng/2014/10/why-clarionchukwurah-is-against-entertainers-going-into-politics/ . Accessed 30 January 2016.

Itiri, N. (2015), 'From entertainment to politics: Nigerian celebrities and the 2015 general elections', VUNA Journal of History and International Relations, 2:2, pp. 249-57.

Jackson, D. and Darrow, T. (2005), 'The influence of celebrity endorsements on young adults' political opinions', Harvard International Journal of Press/Politics, 10:3, pp. 80-98.

Lilywfu (2013), 'Celebrity idolization and their influence in politics', Talking Politics, 12 April, https://talkingpoliticsjomc.wordpress.com/2013/04/12/celebrity-idolization-and-theirinfluence-in-politics/. Accessed 26 May 2016.

McCracken, G. (1989), 'Who is the celebrity endorser? Cultural foundation of the endorsement process', Journal and Consumer Research, 16:3, pp. 310-21.

Michael, M. (2015), 'No Baga group rallies for peaceful election', The Nation, 14 March, http://thenationonlineng.net: http://thenationonlineng.net/no-baga-group-rallies-for-peacefulelection/. Accessed 17 February 2016. 
This is the version of the article accepted for publication in Journal of African Media Studies published by Intellect doi: 10.1386/jams.9.3.487 1

Accepted version downloaded from SOAS Research Online: http://eprints.soas.ac.uk/32045

Moore, M. (2007), 'Oprah becomes test of what an endorsement means', USA Today, 22 October, p. 1A.

Nownes, A. J. (2012), 'An experimental investigation of the effects of celebrity support for political parties in the United States', American Politics Research, 40:3, pp. 476-500.

O'Regan, V. (2012), 'Celebrities and their political opinion', WPSA, http://wpsa.research.pdx.edu/meet/2012/o'reganvalerie.pdf. Accessed 20 November 2015.

(2014), 'The celebrity influence: Do people really care what they think?', Celebrity Studies, 5:4, pp. 469-83.

Ohanian, R. (1990), 'Construction and validation of a scale to measure celebrity endorser's perceived expertise, trustworthiness and attractiveness', Journal of Advertising, 19:3, pp. 3952.

Payne, J. G., Hanlon, J. P., and Tworney, D. P. (2007), 'Celebrity spectacle influence on young voters in the 2004 presidential campaign', American Behavioral Scientist, 50:9, pp. 1239-46.

Ratneshwar, S. and Chaiken, S. (1991), 'Comprehension's role in persuasion: The case of its moderating effect on the persuasive impact of source cues. Journal of Consumer Research, 18:1, pp. 52-62.

Ridley, S. (2010). The importance of celebrities in political decision making: A rhetorical analysis of the Barack Obama Presidential campaign. North Carolina: Unpublished doctoral dissertation, Wake Forest University.

Scarborough (2013), 'Democratic voter base highly influenced by celebrity endorsements', 8 March, Dialog, http://dialog.scarborough.com/index.php/democrat-voter-base-highlyinfluenced-by-celebrity-endorsements/. Accessed 29 May 2016.

Schroeder, A. (2004), 'Celebrity-in-chief: how show business took over the White House', Boulder Colorado: Westview Press.

Shipman, M. (2010), 'Celebrity endorsements do not help political candidates', NC State University, 26 April, https://news.ncsu.edu/2010/04/wmscobbcelebrity/. Accessed 24 May 2016.

Street, J. (2002), 'Bob, Bono and Tony B: The popular artist as politician', Media, Culture and Society, 24:3, pp. 433-41.

Tsika, N. (2015), Nollywood Stars: Media and Migration in West Africa and the Diaspora, Bloomington: Indiana University Press. 
This is the version of the article accepted for publication in Journal of African Media Studies published by Intellect doi: 10.1386/jams.9.3.487 1

Accepted version downloaded from SOAS Research Online: http://eprints.soas.ac.uk/32045

West, D. and Orman, J. (2002), Celebrity Politics, New Jersey: Prentice Hall.

Wood, N. T. and Herbst, K. C. (2007). Political Star Power and Political Parties:Does Celebrity Endorsement Win First-Time Votes. Journal of Political Marketing, 6:2-3, pp. 14158. 